\section{Unusual Conditions \\ of Superconductivity and Itinerant Magnetism DFG - SRC - CRNS Round Table, Bad Honnef, 21-23 May}

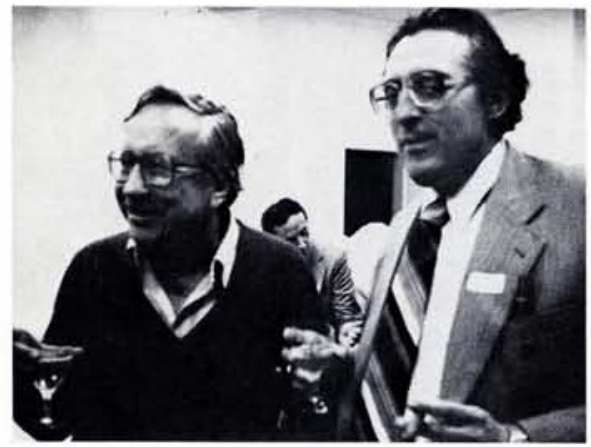

B.T. Matthias, La Jolla (left) and F.M. Müller, Nijmegen, after placing a $\$ 500$ bet on whether it will be possible within the next four years to find a new high temperature superconductor $\left(T_{c}>20 \mathrm{~K}\right)$ by bandstructure calculations alone.

As in many fields of science, so also in solid state physics, from time to time a certain malaise sets in. The reason for this is that in the eyes of a few, no unsolved problems remain.

The Round Table discussion in Bad Honnef came therefore, as a startlingly refreshing change. Ever since the role played by the Cooper pairs in a singlet state for the occurrence of superconductivity became evident, many speculations as to the effect of pairs in a triplet state have appeared in the literature. Recently a radically new and opposite assumption was expressed, suggesting that triplet pairs may not lead to superconductivity at all, as previously assumed, but to itinerant magnetism instead. This idea has not only given impetus to a fairly large number of theorists, but has also stimulated the experimentalists to make a greatly expanded effort along the lines of a triplet ground state.

As usual, drastically new ideas have not been accepted by all at once and with equal enthusiasm. The gathering in Bad Honnef was therefore an ideal occasion to exchange views and criticisms - and accelerate and develop ideas about a triplet ground state. At the same time there was the hope of arriving at a jelling of a consensus, if this was at all possible. In this respect, the results undoubtedly exceeded all expectations even though a real consensus was reached only in so far as the critical and sensitive nature of any $\mathrm{p}$. state pairing was concerned. The phase transition and superfluidity of helium 3 give already experimental proof and all theories join to confirm the sensitivity of such a transition.

At the Honnef gathering a new itinerant ferromagnet of the formula $\mathrm{TiBe}_{1.75} \mathrm{Cu}_{0.25}$ was announced. This is the third to be known among more than 10000 intermetallic compounds!! Some of the results communicated were so recent, that many of the participants were caught totally unawares and were not yet prepared to take a definite stand. This situation ranged from irradiated superconducting palladium to the isotope effects in magnetic materials never heretofore found. It covered radically new calculations on $\mathrm{ZrZn}_{2}$ to valence fluctuations in rare earth compounds including both experimental and theoretical results. This last subject caused tempers to flare quite a bit.

All in all, the encounter in Bad Honnef was probably the decisive trigger to some startling developments, both experimental and theoretical, in the physics of phase transitions which are due to highly unusual conditions and depend on very special circumstances.

\section{B. T. Matthias}

\section{Society News}

\section{Divisions}

The new Chairman of the Atomic Spectroscopy Section of the Atomic Physics Section, EGAS, is: Prof. B. Cagnac, Lab. de Spectroscopie Hertzienne de I'ENS, Université Pierre et Marie Curie, 4, place Jussieu, F-75230 Paris. The Secretary remains A. Dönszelmann.

The complete list of Board Members of the Atomic Physics Division is:

E.W. Otten, Mainz, Chairman

I. Martinson, Lund, Secretary

R.J. Damburg, Riga

H.G. Gilbody, Belfast

W. Kolos, Warsaw

J.C. Lehmann, Paris

Representatives of Sections:

J. Depireux, Liège

F.J. Comes, Frankfurt/Main

F. Linder, Kaiserslautern

F.H. Read, Manchester

B. Cagnac, Paris

A. Dönszelmann

E.A.C. Lucken, Geneva

G. Wagnière, Zurich and Co-opted Members:

T. Andersen, Aarhus

F.-A. Gianturco, Bari

I. Kovacs, Budapest

S. Leach, Orsay

M. Leduc, Paris

R.M.C. McDowell, Egham, UK

To the list of Board Members of the Condensed Matter Division should be added the name of the co-opted member:

J.T. Devreese of RUCA, Antwerp Chairman and main organizer of the 1980 annual divisional conference (see over).

Note that in the Board of the Plasma Physics Division, A. Sestero is of CNEN, Frascati.

\section{National Society}

The new President of the French Physical Society is L. Michel of the Institut des Hautes Etudes Scientifiques of Bures-sur-Yvette.

\section{New Individual Ordinary Members}

\section{CATEGORY 4 A}

C. Avilez, Mexico, Mexico

E. Bertolini, Abingdon, UK

\section{CATEGORY $4 \mathrm{C}$}

Austrian Physical Society

J. Koppelmann, Leoben

Belgian Physical Society C. Joachain, Brussels L. Stals, Diepenbeek H. Van Dael, Kortrijk

French Physical Society C. Montes, Nice J. Suzanne, Marseilles

The Institute of Physics S.G. Coutinho, Orsay, F A. Evans, Keele

A. Evans, Kuggle, Jülich, D

J.C. Fuggle, Jülich, D
J.M. Irvine, Manchester

R.D. Murley, Middlesbrough

F. Steglich, Darmstadt
German Physical Society H.-U. Chun, Frankfurt/Main K.H. Hesselbacher, Stuttgart R. Hippler, Bielefeld H. Keiter, Dortmund

J. Keller, Regensburg

J. Krutein, Stelzenberg

F. Linder, Kaiserslautern

H. Merz, Münster

V. Oestreich, Karlsruhe

J. Peisl, München

B. Raith, Bochum

S. Roth, Stuttgart

H. Schultz, Stuttgart

C. Varelas, Garching

Italian Physical Society

O. Bisi, Modena

G.P. Brivio, Milan

S. Fubini, Geneva, $\mathrm{CH}$

The Netherlands' Physical Society

H.G.M. Heideman, Utrecht

P.H. Kes, Leiden
Polish Physical Society

A. Bluszcz, Gliwice

G. Czajkowski, Bydgoszcz

J. Czerwonko, Wroclaw

K. Fialkowski, Krakow

Z. Galasiewicz, Wroclaw

W. Jakubowski, Warsaw

A. Jaskiewicz, Wroclaw

F. Kaczmarek, Poznan

S. Kielich, Poznan

T. Krajewski, Poznan

M. Kwietniak, Warsaw

J. Morkowski, Poznan

A.M. Oles, Krakow

Z. Pajak, Poznan

H. Puszkarski, Poznan

A. Radlinski, Warsaw

M. Rozwadowski, Bydgoszcz

Z. Sidorski, Wroclaw

B. Sredniawa, Krakow

W. Szuszkiewicz, Warsaw

P. Swiatek, Wroclaw

A. Sukiennicki, Warsaw

K. Wojciechowski, Wroclaw

L. Zybert, Krakow

R. Zybert, Krakow
Norwegian Physical Society

K.H. Alfsen, Oslo

Physical Section,

Union of Czechoslovak Mathe-

maticians and Physicists

L. Kratena, Prague

M. Kucharski, Prague

Physical Section,

Union of Yugoslav Societies of Mathematicians, Physicists and Astronomers

M. Todorovic, Belgrade

Romanian National Committee for Physics

G. Semenescu, Bucharest

Swedish Physical Society

C. Bargholtz, Tyresö

$\mathrm{P}$.-O. Orrhede, Värnamo

K. Pernestal, Uppsala

J.E. Richert, Lottorp

Swiss Physical Society

K. Appert, Lausanne 